\title{
PENERAPAN METODE MAKE A MATCH UNTUK MENINGKATKAN HASIL BELAJAR IPSPADA SISWA KELAS III SDN 1 JENANGANPONOROGO
}

\author{
Siti Nur Nahdiyatin \\ SDN 1 Jenangan Kecamatan Jenangan Kabupaten Ponorogo \\ Email: mrsirhamni@yahoo.co.id
}

\begin{abstract}
Abstrak
Penelitian ini bertujuan untuk mengetahui peningkatan hasil belajar IPS dengan menggunakan metode Make A Match pada siswa kelas III SDN 1 Jenangan Kecamatan Jenangan Kabupaten Ponorogo. Penelitian ini menggunakan pendekatan kualitatif dan jenis penelitiannya adalah penelitian tindakan kelas. Penelitian ini dilaksanakan sebanyak dua siklus dan dilaksanakan pada semester genap tahun pelajaran 2015/2016. Subyek penelitian ini adalah siswa kelas III SDN 1 Jenangan yang berjumlah 22 siswa. Dari penelitian yang dilakukan menunjukkan bahwa dengan menerapkan metode make a match dapat meningkatkan hasil belajar IPS siswa kelas III SDN 1 Jenangan.Hal ini dibuktikan dengan nilai rata-rata kelas yang mengalami kenaikan.Pada pra siklus nilai rata klasikal siswa $=61,55$, siklus II $=70,00$, siklus III $=79,23$. Jika dilihat dari nilai KKM, pada pra siklus terdapat 9 siswa yang mendapatkan nilai diatas KKM atau sebesar 40,91\% dan 13 siswa masih berada di bawah KKM (59,09\%). Pada siklus I ada 15 siswa yang nilai diatas KKM $(68,18 \%)$, terdapat kenaikan sebesar $27,27 \%$. Sementara siswa yang mendapatkan nilai dibawah KKM menurun menjadi 7 siswa $(31,82 \%)$. Sedangkan pada siklus II jumlah siswa yang mendapatkan nilai di atas KKM yaitu 20 siswa $(90,91 \%)$ dan masih ada 2 siswa dibawah KKM $(9,09 \%)$.
\end{abstract}

Kata kunci: Metode Make A Match, Hasil Belajar IPS

\section{The Implemention of Make A M atch M ethodT o I mprove the Third G rade Students' Learning Outcomes of Social ScienceIn SDN 1 Jenangan Ponorogo}

\begin{abstract}
Abstrack
This study aims to know the improvement of learning outcomes of social science using Make A Match method for the third grade students of SDN 1 Jenangan-Ponorogo city. This study uses qualitative approach and Classroom Action Research. The study was conducted in two cycles and conducted in the second term of school year 2015/2016 in SDN 1 Jenangan. The subject of this study is third grade students of SDN 1 Jenangan,consisting of 22 students. The result show that learning outcomes of social science for the third gradestudents of SDN 1 Jenangan- in the second term of the school year 2015/2016 can be improved by using Make A Match method.It can be clearly seen that the students' average classical scores has increased. In the pre cycle, the students' average classical score is 61.55, while it is 70.00 in the cycle I and then in the cycle II it is 79.23. In the pre cycle the students who achieve the parameter of KKM is 9 students (40,91\%), and the students who cannot achieve the parameter, are 13 students or at 59,09\%. Meanwhile, In the cycle I, there are 15 students who achieve the parameter of KKM at 68,18\%, and the students who cannot achieve the parameter, are 7 students or at 31,82, it increases about $27,27 \%$. Further, in the cycle II, there are 20 students who achieve the parameter of KKM at 90,91\% and 2 students cannot achieve the parameter at 9,09\%.
\end{abstract}

Keyword: Make a match method, Learning outcome, Social Science (IPS) 
Avaliable online at http://e-journal.ikippgrimadiun.ac.id/index.php/gulawentah

\section{Pendahuluan}

Dalam perkembangan ilmu pengetahuan dan teknologi, pendidikan merupakan salah satu faktor penting.Pendidikan Nasional di Indonesia berdasarkan Pancasila bertujuan untuk meningkatkan kualitas manusia Indonesia seutuhnya lahir dan batin. Manusia yang bertaqwa kepada Tuhan Yang Maha Esa, berbudi pekerti luhur, kepribadian, berdisiplin, bekerja keras, tangguh, bertanggung jawab, mandiri, cerdas, terampil, sehat jasmani dan rohani, berdedikasi tinggi serta peningkatan taraf hidup (Undang Undang Nomor 20 Tahun 2003).Untuk mewujudkan tujuan pendidikan nasional di atas diperlukan kurikulum. Di SDN 1 Jenangan Kecamatan Jenangan Kabupaten Ponorogo masih menggunakan dua jenis kurikulum yaitu Kurikulum Tingkat Satuan Pendidikan (KTSP) untuk kelas II, III, V, VI dan Kurikulum 2013 untuk kelas I dan IV. Khusus untuk mata pelajaran IPS diperuntukkan bagi siswa yang tidak menggunakan kurikulum 2013.Materi pelajarannya merupakan keterpaduan antara materi geografi, sejarah, sosiologi, dan ekonomi.Pelajaran IPS SD pada kelas 1-3 dilaksanakan melalui pendekatan tematik, sedangkan pada kelas 4-6 dilaksanakan melalui pendekatan pelajaran.Mata pelajaran IPS disusun secara sistematis, komprehensif, dan terpadu dalam proses pembelajaran menuju kedewsaan dan keberhasilan dalam kehidupan di masyarakat. Dengan pendekatan tersebut diharapkan siswa akan memperoleh pemahaman yang lebih luas dan mendalam pada bidang ilmu yang berkaitan. Namun masih sering dijumpai pembelajarannya lebih terpusat pada guru.Sehingga siswa kurang terampil menjawab pertanyaan atau bertanya tentang konsep yang diajarkan.Siswa kurang bisa bekerja dalam kelompok diskusi dan pemecahan masalah yang diberikan.Mereka cenderung belajar sendiri-sendiri.Pengetahuan yang didapat bukan dibangun sendiri secara bertahap oleh siswa atas dasar pemahaman sendiri.Karena siswa jarang menemukan jawaban atas permasalahan atau konsep yang dipelajari.

Cara pembelajaran tersebut di atas membuat pembelajaran menjadi monoton.Siswa bersikap acuh tak acuh, menjadi bosan, tidak fokus dalam pelajaran, ramai dan tidak memperhatikan penjelasan dari guru.Hanya sebagian kecil dari para siswa yang memperhatikan penjelasan dari guru.Sebagian besar siswa malah terlihat asyik dengan kegiatan mereka sendiri, seperti bermain kertas dan bercakap-cakap dengan teman sebangku.Siswa menjadi kurang termotivasi dalam belajar.Mereka menganggap bahwa pelajaran IPS adalah pelajaran yang membosankan, mereka hanya duduk, mendengar, dan jika waktu ceramah selesai mereka harus mengerjakan tugas yang diperintahkan.

Pada kenyataannya tidak demikian yang terjadi di SDN 1 Jenangan Kecamatan Jenangan Kabupaten Ponorogo.Dalam pembelajaran IPS, guru kelas III masih mendominasi pembelajaran di kelas.Metode yang banyak digunakan hanyalah ceramah, dan hanya sesekali melakukan timbal balik dengan para siswa.Media yang digunakan hanya buku pegangan siswa dan Lembar Kerja Siswa saja.Padahal di kelaslah segala sesuatunya akan bertemu; seperti guru dengan segala kemampuannya, siswa dengan segala latar belakang dan potensinya, kurikulum 
dengan segala komponennya, metode dengan segala pendekatannya, media dengan segala perangkatnya, materi dengan segala sumber belajarnya bertemu dan berinteraksi di dalam kelas.

Kondisi kelas dalam penjelasan di atas diperoleh melalui pengamatan yang dilakukan selama bulan Februari dan Maret 2016, pada semester II tahun pelajaran 2015-2016.Selain melakukan pengamatan, dikumpulkan pula hasil evaluasi belajar para siswa.Dari berbagai dokumen yang telah terkumpul diperoleh data bahwa prosentase ketuntasan belajar yang diperoleh minim atau jauh dari harapan guru.KKM yang ditetapkan di SDN 1 Jenangan untuk mata pelajaran IPS adalah 75. Dari jumlah siswa sebayak 22 siswa, hanya 9 siswa yang mendapatkan nilai di atas KKM atau jika diprosetase hanya sebesar 40,91\%. Sementara 13 siswa mendapatkan nilai dibawah KKM (59,09\%). Rendahnya pencapaian nilai akhir siswa ini, menjadi indikasi bahwa pembelajaran yang dilakukan selama ini belum efektif.Nilai akhir dari evaluasi belajar belum mencakup penampilan dan partisipasi siswa dalam pembelajaran, hingga sulit untuk mengukur keterampilan siswa.Kondisi yang demikian, membuat guru harus berupaya mencari metode pembelajaran yang menarik dan bervariasi supaya target KKM yang diharapkan bisa tercapai.

Banyak metode pembelajaran yang telah diterapkan oleh para pendidik, semuanya bertujuan agar proses belajar mengajar menjadi efektif dan efisien sehingga tujuan pembelajaran dapat tercapai. Yang tidak kalah pentingnya, siswa dapat menganalisa pelajaran IPS berdasarkan fakta dan data yang ditemukan dalam berbagai sumber.Salah satu dengan metode alternatifnya yaitu metode "Make AMatch".

Menurut Rusman (2013: 223-233) make a match (membuat pasangan) merupakan salah satu jenis dari metode dalam pembelajaran kooperatif. Metode ini dikembangkan oleh Lurna Curran pada tahun 1994. Salah satu keunggulan metode ini adalah peserta didik mencari pasangan sambil belajar mengenai suatu konsep atau topik dalam suasana yang menyenangkan. Lie (2008:56) juga menyatakan bahwa metode ini memberi kesempatan siswa untuk bekerja sama dengan orang lain. Teknik ini bisa digunakan dalam semua mata pelajaran dan untuk semua tingkatan usiasiswa didik.Huda (2013:253) menegaskan bahwa metode make a matchdapat meningkatkan aktivitas belajar siswa, baik secara kognitif maupun fisik karena terdapat unsur permainan dan menjadikan metode ini menyenangkan.

Imas (2015:55) menyampaikan langkah-langkah pembelajaran IPS di sekolah dasar dengan menggunakan metode make a match yaitu (1) Guru menyiapkan beberapa kartu yang berisi beberapa konsep atau topik yang cocok untuk sesi review, satu bagian kartu soal dan bagian lainnya kartu jawaban, (2) Setiap siswa mendapatkan sebuah kartu yang bertuliskan soal/jawaban, (3) Tiap siswa memikirkan jawaban/soal dari kartu yang dipegang, (4) Setiap siswa mencari pasangan kartu yang cocok dengan kartunya. Misalnya: pemegang kartu yang bertuliskan nama tumbuhan dalam bahasa Indonesia akan berpasangan dengan nama tumbuhan dalam bahasa latin (ilmiah), (5) Setiap siswa yang dapat mencocokkan kartunya sebelum batas waktu diberi poin, 
Avaliable online at http://e-journal.ikippgrimadiun.ac.id/index.php/gulawentah

(6) Jika siswa tidak dapat mencocokkan kartunya dengan kartu temannya (tidak dapat menemukan kartu soal atau kartu jawaban) akan mendapatkan hukuman, yang telah disepakati bersama, (8) Setelah satu babak, kartu dikocok lagi agar tiap siswa mendapat kartu yang berbeda dari sebelumnya, demikian seterusnya, (9) Siswa juga bisa bergabung dengan 2 atau 3 siswa lainnya yang memegang kartu yang cocok, (10) Guru bersama-sama dengan siswa membuat kesimpulan terhadap materi pelajaran.

Salah satu indikator tercapai atau tidaknya suatu proses pembelajaran adalah dengan melihat hasil belajar yang dicapai oleh siswa. Hasil belajar merupakan cerminan tingkat keberhasilan atau pencapaian tujuan dari proses belajar yang telah dilaksanakan yang pada puncaknya diakhiri dengan suatu evaluasi. Hasil belajar diartikan sebagai hasil akhir pengambilan keputusan tentang tinggi rendahnya nilai siswa selama mengikuti proses belajar mengajar, pembelajaran dikatakan berhasil jika tingkat pengetahuan siswa bertambah dari hasil sebelumnya. Hasil belajar merupakan kemampuan internal (kapabilitas) yang meliputi pengetahuan, ketrampilan dan sikap yang telah menjadi milik pribadi seseorang dan memungkinkan seseorang melakukan sesuatu.Pendapat tentang hasil belajar dikemukakan oleh Jenkins dan Unwin (dalam Uno, 2011:17) yang mengatakan bahwa hasil belajar adalah pernyataan yang menunjukkan tentang apa yang mungkin dikerjakan siswa sebagai hasil dari kegiatan belajarnya. Jadi hasil belajar merupakan pengalaman-pengalaman belajar yang diperoleh siswa dalam bentuk kemampuan-kemampuan tertentu.
Hasil belajar siswa dapat diperoleh guru terlebih dahulu dengan memberikan seperangkat tes kepada siswa untuk menjawabnya.Tes tersebut bisa berupa lisanatau tulisan. Penilaian bisa dilakukan oleh guru pada saat pembelajaran akan dimulai, saat berlangsung atau pada akhir pembelajaran. Hasil tes tersebut akan memberikan gambaran informasi tentang kemampuan dan penguasaan kompetensi siswa pada suatu materi pelajaran yang kemudian dikonversi dalam bentuk angkaangka. Hasil belajar dapat dikatakan tuntas apabila telah memenuhi kriteria ketuntasan minimum yang ditetapkan oleh masingmasing sekolah.Antar sekolah terkadang memiliki KKM yang berbeda pada tiap mata pelajaran. Hal ini disebabkan KKM disusun berdasarkan oleh beberapa indikator (intake/daya dukung, sarana dan prasana, stake holder dan lain-lain) yang terkadang tidak sama antara satu sekolah dengan sekolah yang lain.

Berangkat dari uraian di atas, apakah penerapan metode make to match dapat meningkatkan hasil belajar siswa kelas III SDN 1 Jenangan?. Untuk itu maka penelitian ini menarik dan perlu dilakukan guna mengetahui peningkatan hasil belajar IPS setelah guru melakukan pembelajaran IPS dengan menggunakan metode make a match.

\section{Metode Penelitian}

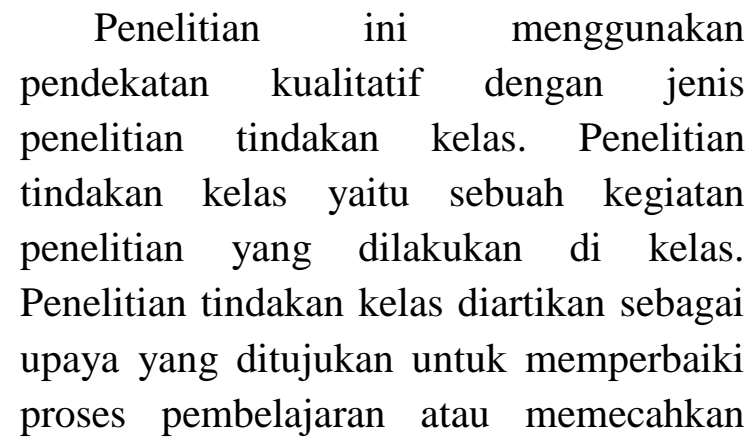


gulawentah: Jurnal Studi Sosial

Volume 1 Nomor 2 Desember 2016, hal. 81-90

Avaliable online at http://e-journal.ikippgrimadiun.ac.id/index.php/gulawentah

masalah yang dihadapi dalam tindakan kelas yang dikemukakan pembelajaran (Mulyasa, 2011: 34).

Prosedur penelitian untuk Arikunto, dkk. (2006: 16), dimana tahapmelaksanakan tindakan penelitian kelas ini berdasarkan pada prosedur penelitian

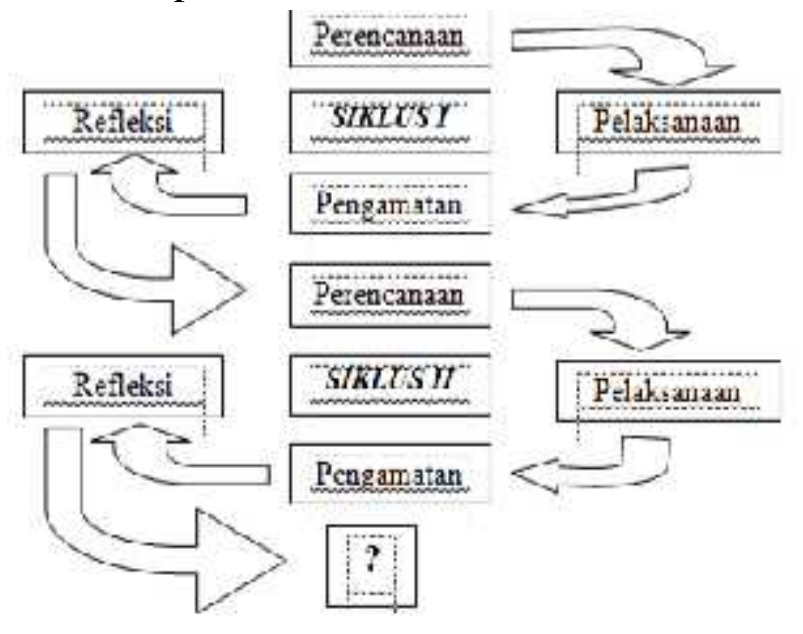

Gambar 1. Bagan Siklus Penelitian Tindakan Kelas (Arikunto, 2016: 42 )

PTK ini dilakukan secara kolaborasi dengan bantuan teman sejawat, yaitu guru kelas VI sebagai pengamat.Teman sejawat bertugas untuk mencatat kelebihan dan kekurangan guru dan murid dari awal sampai akhir pembelajaran.Sementara guru bertindak sebagai pihak yang melakukan pembelajaran atau tindakan sekaligus sebagai peneliti. Bantuan dari teman sejawat ini dilakukan agar guru bisa lebih fokus terhadap proses pembelajaran di kelas.

Penelitian ini dilaksanakan pada
semester genap tahun pelajaran

2015/2016bulan Februari sampai dengan Maret 2016di kelas III SDN 1 Jengangan Kecamatan Jenagan Kabupaten Ponorogo dengan jumlah subjek penelitian 22 siswa yang terdiri dari 9 laki-laki dan 13 perempuan.

Penyusunan indikator kinerja penelitian bertujuan untuk menentukan keberhasilan dari rencana penelitian yang telah disusun.Angka-angka yang didapat dijadikan sebagai pedoman atau ukuran terhadap keberhasilan indikator kinerja.

Tabel 1. Indikator Kinerja Penelitian

\begin{tabular}{|c|c|c|}
\hline Rumusan Masalah & Tujuan & Indikator Kinerja \\
\hline $\begin{array}{l}\text { Bagaimana meningkatkan } \\
\text { prestasi belajar IPS dengan } \\
\text { menggunakan metode make a } \\
\text { match pada siswa kelas III } \\
\text { SDN 1 Jenangan Kabupaten } \\
\text { Ponorogo }\end{array}$ & $\begin{array}{l}\text { Untuk mengetahui peningkatan } \\
\text { prestasi belajar IPS dengan } \\
\text { menggunakan metode make a } \\
\text { match pada siswa kela III SDN } \\
1 \quad \text { Jenangan Kabupaten } \\
\text { Ponorogo }\end{array}$ & 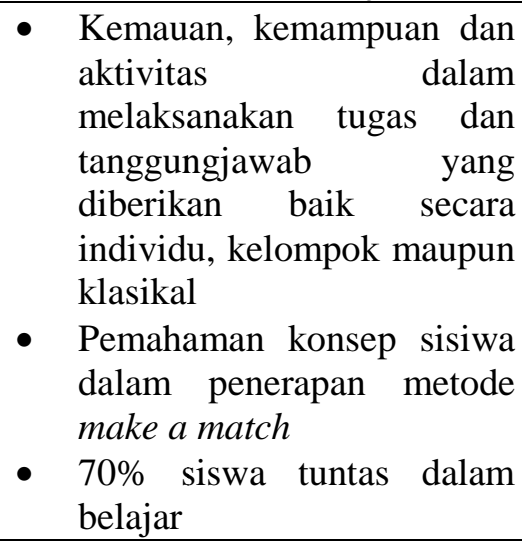 \\
\hline
\end{tabular}


Dari tabel di atas memberi gambaran bahwa permasalahan yang terjadi adalah menurunnya prestasi belajar siswa dalam mata pelajaran IPS, dan diharapkan dengan penerapan model belajar kooperatif dengan metodemake a match dapat meningkatkan prestasi belajar siswa. Angka-angka yang diperoleh melalui evaluasi yang dilaksanakan akan digunakan untuk menentukan capaian hasil belajar IPS sesuai dengan KKM yang ditetapkan di SDN 1 Jenangan yaitu 75. Sedangkan secara klasikal, dikatakan tuntas, jika telah mencapai minimal $70 \%$ atau lebih.Jika data-data yang diperoleh telah memenuhi syarat maka langkah yang dilakukan dikatakan dapat meningkatkan hasil ketuntasan dalam belajar.

\section{Hasil dan Pembahasan}

Dari hasil yang telah diperoleh pada awal observasi, ditemukan rendahnya hasil belajar siswa. Hal ini disebabkan cara mengajar yang terpusat pada guru, membuat pembelajaran menjadi monoton. Siswa bersikap acuh tak acuh, menjadi bosan, tidak fokus dalam pelajaran, ramai dan tidak memperhatikan guru.Secara individu, siswa dinyatakan tuntas dalam pembelajaran IPS jika telah mencapai standar Kriteria Ketuntasan Minimal (KKM) yang telah ditetapkan yaitu sebesar 75.

$\begin{array}{clr}\text { Guru } & \text { dalam melaksanakan } \\ \text { pembelajaran } & \text { sebelumnya } & \text { (prasiklus) }\end{array}$ hanya memanfaatkan buku pegangan dan lembar kerja siswa yang telah tersedia.

Metode yang digunakan hanya ceramah dan jarang memberikan umpan balik atau mengajak siswa berdiskusi. Nilai yang diambil guru berasal dari Ulangan
Harian (UH), Pekerjaan Rumah (PR), Ulangan Tengah Semester (UTS) dan Ulangan Akhir Semester (UAS) . Sedangkan nilai sikap pada saat diskusi kelompok atau nilai partisipatif kurang diperhatikan guru.

Hasil evaluasi pembelajaran dengan pemberian tindakan kelas diperoleh data bahwa dari 22 siswa, hanya 9 siswa yang mendapatkan nilai diatas KKM atau 40,91\%. Sementara 13 siswa lainnya masih berada dibawah KKM atau 59,09\%. KKM yang ditetapkan di Kelas III SDN 1 Jenangan untuk mata pelajaran IPS yaitu sebesar 75. Data di atas menunjukkan bahwa hasil belajar IPS siswa kelas III masih berada dibawah rata-rata nilai yang ditetapkan yaitu $70 \%$ siswa mencapai ketuntasan.

\section{Siklus I}

Sebelum diberi tindakan penelitian rata-rata pada pra siklus adalah 61,55 dan setelah diberi tindakan, rata-rata pada siklus I mengalami kenaikan menjadi 70.00. Terdapat kenaikan sebesar 8.45. 
Avaliable online at http://e-journal.ikippgrimadiun.ac.id/index.php/gulawentah

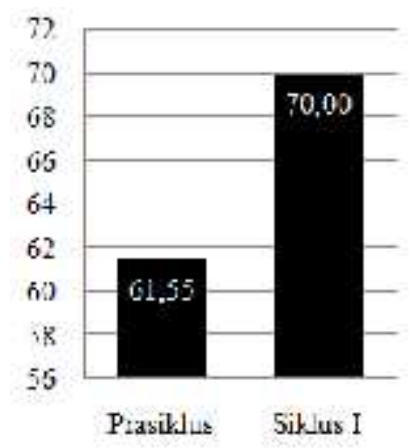

Gambar2. Nilai Rata-rata Prasiklus danSiklus 1

Jumlah siswa yang mencapai KKM pada siklus I juga telah mengalami kenaikan. Jika pada pra siklus hanya terdapat 9 siswa yang mendapatkan nilai diatas KKM atau 40,91\% sedangkan 13 siswa masih mendapatkan nilai dibawah KKM atau $59,09 \%$ maka pada siklus I ini naik menjadi 15 siswa yang mendapatkan nilai di atas KKM atau menjadi $68,18 \%$.

Rata-rata yang diperoleh pada siklus I sudah mencapai batas minimal dari ratarata yang diharapkan yaitu sebesar
70.Perbandingan dan kenaikan nilai ratarata tersebut terlihat seperti pada gambar 2.Sementara siswa yang mendapatkan nilai dibawah KKM turun menjadi 7 siswa atau sebesar $31,82 \%$. dari 13 siswa yang ada pada pra siklus. Terdapat kenaikan sebesar $27,27 \%$ untuk siswa yang mendapatkan nilai di atas KKM. Perbandingan prosentase dan kenaikan nilai KKM pada siklus I terlihat pada gambar 3 di bawah ini.

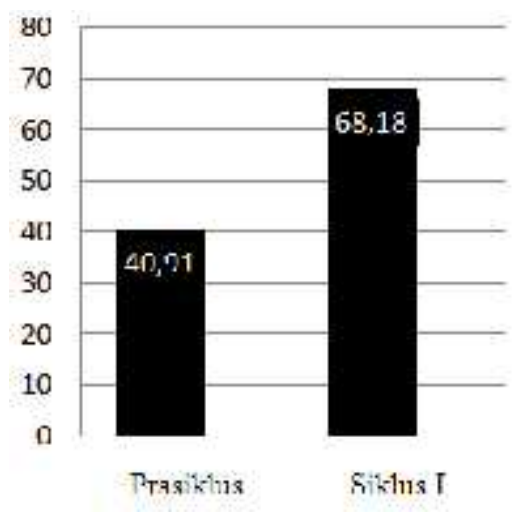

Gambar 3 Persentase Capaian KKM Prasiklus dengan Siklus 1

Dari dua gambar terlihat bahwa tabel capaian minimal KKM sebesar $70 \%$ belum terpenuhi, karena itu penelitian tindakan masih perlu dilakukan dengan melakukan beberapa perbaikan.

Kekurangan guru yang masih terlihat adalah kurang jelasnya instruksi yang diberikan kepada para siswa, mengingat ini adalah metode pembelajaran yang baru saja diterima oleh siswa.Kegaduhan juga sempat terjadi karena kurang kontrolnya guru. Siswa masih terlihat bingung dengan apa yang harus mereka kerjakan.
Ketidakpahaman mereka menjadikan para siswa terlihat kurang aktif dalam pembelajaran, guru juga belum banyak memberikan motivasi kepada para siswa.Selain itu kontrol waktu tidak diberikan oleh guru sehingga waktu pembelajaran telah habis namun guru belum sampai pada tahap kesimpulan pembelajaran atau kegiatan penutup. Berdasarkan analisa di atas, maka siklus II perlu dilakukan untuk mengetahui bagaimana penerapan metode Make A Match ini. 
gulawentah: Jurnal Studi Sosial

Volume 1 Nomor 2 Desember 2016, hal 81-90

Avaliable online at http://e-journal.ikippgrimadiun.ac.id/index.php/gulawentah

Siklus II

Pada siklus II ini lebih difokuskan pada pembenahan dan pengoptimalan siswa dan guru. Guru harus membenahi lagi kekurangan atau kelemahan yang terdapat pada siklus I. Guru juga harus lebih mengaktifkan lagi para siswa sebagai subjek dan juga objek dalam pembelajaran. Mereka perlu diberi motivasi, bimbingan dan arahan yang lebih jelas dalam melakukan tugasnya singkat, Penjelasan yang diberikan kepada siswa hendaknya sederhanatetapi harus jelas.Pembenahan atau perbaikan yang dilakukan pada siklus II ini bertujuan untuk memaksimalkan penerapan metode Make A Match pada pembelajaran IPS di kelas III.

Pada siklus II ini terdapat kenaikan rata-rata yang diperoleh. Jika pada siklus I telah tercapai batas minimal sebesar 70,00maka pada siklus II ini naik menjadi 79,23. Terdapat kenaikan sebesar 9,23 dari siklus I. Perbandingan dan kenaikan nilai rata-rata terlihat pada gambar 4 dibawah ini

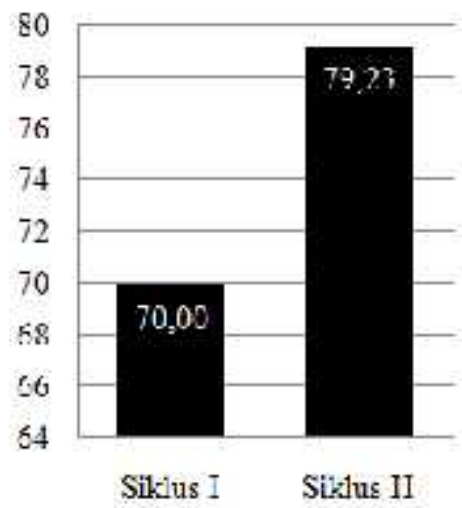

Gambar 4 Nilai Rata-rata Siklus 1 dan Siklus 2

Jumlah siswa yang mendapatkan nilai di atas KKM juga mengalami kenaikan pada siklus II ini. Jika pada siklus I terdapat 15 siswa yang mendapatkan nilai diatas KKM (68,18\%) maka pada siklus II sebanyak 20 siswa yang mendapatkan nilai di atas KKM atau 90,91\%. Hal berarti penerapanmetode make a match dapat meningkatkan hasil belajar IPS di kelas III.Sementara penurunan juga terjadi pada siswa yang mendapatkan nilai dibawah KKM. Jika pada siklus I terdapat 7 siswa yang masih mendapatkan nilai di bawah KKM, maka pada siklus II jumlah siswa yang mendapatkan nilai di bawah KKM menurun menjadi 2 orang saja atau sebesar 9,09\%. Hal itu terlihat pada gambar 5 .

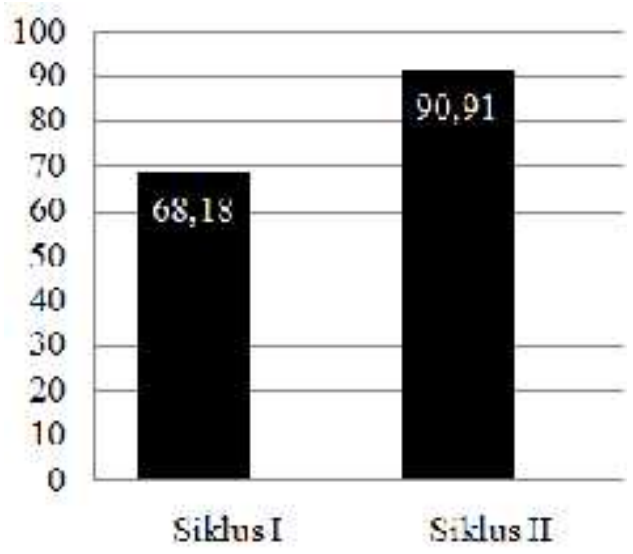

Gambar 5 Persentase Capaian KKM Siklus 1 dengan Siklus 2 
Nilai rata-rata mulai pra siklus, siklus I dan siklus II juga terus mengalami kenaikan.Peningkatan nilai rata-rata secara klasikal terlihat seperti pada gambar 6 di bawah ini

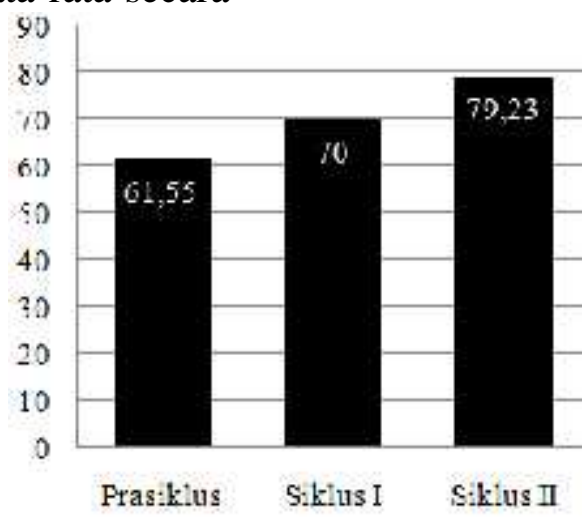

Gambar 6 Peningkatan Rata-rata Nilai Klasikal

Gambar di atas memberi petunjuk bahwa jumlah siswa yang mencapai nilai diatas dan atau sama dengan Kriteria Ketuntasan Minimal (KKM) yang ditetapkan di SDN 1 Jenangan Kecamatan Jenangan sebelum pemberian tindakan dan

\section{Kesimpulan dan Saran}

Hasil peneliti yang telah disampaikan di atas terlihat dengan jelas hasil belajar IPS siswa kelas III SDN 1 Jenangan Kecamatan Jenangan Kabupaten Ponorogo mengalami kenaikan. Pada pra siklus terdapat $9(40,91 \%)$ siswa yang mendapatkan nilai hasil belajar diatas KKM. Pada siklus 1 terdapat $15(68,18 \%)$ siswa yang nilai hasil belajar diatas KKM atau mengalami kenaikan sebesar 27,27\%. Sedangkan pada siklus 2 ada 20 siswa $(90,91 \%)$ yang nilai hasil belajarnya di atas KKM atau mengalami kenaikan sebesar 22,72\%. \%). Capaian hasil belajar pada siklus 2 melebihi target ketuntasan yang telah ditetap dan berarti metode pembelajaran ini dapat meningkatkan hasil belajar IPS siswa kelas III SDN 1 Jenagan Kecamatan Jenangan Kabupaten Ponorogo.

Dengan melihat hasil penelitian ini, peneliti menyarankan kepada para guru IPS di sekolah dasar untuk senantiasa memilih metode yang tepat dan bervariasi agar proses pembelajaran lebih menggairahkan dan tujuan pembelajaran dapat diwujudkan.

\section{Daftar Pustaka}

Arikunto, S. dkk.(2016). Penelitian Tindakan Kelas. Jakarta: PT. Bumi Aksara

Depdiknas Dirjen PMPTK. (2007). Landasan Konsep Prinsip dan Strategi PAKEM. Jakarta: Direktorat Pembinaan Diklat.

Fakultas Ilmu Sosial Universitas Negeri Yogyakarta.(2013). Nasib Pendidikan IPS di Kurikulum 2013. http://fis.uny.ac.id.

Huda, M. (2013).Model-Model Pengajaran dan Pembelajaran.Yogyakarta: Pustaka Pelajar

Kurniasih, I dan Berlin, S. (2015).Ragam Pengembangan Model Pembelajaran Untuk Peningkatan Profesionalitas Guru.Jogjakarta: Kata Pena

Lie, A. (2008). Cooperative Learning. Jakarta: PT Grasindo

Mulyasa, E. (2011). Praktik Penelitian Tindakan Kelas. Bandung: PT Remaja Rosdakarya

Rusman. (2011).Model-model Pembelajaran Mengembangkan Profesionalisme Guru. Jakarta: Rajawali Pers. 
gulawentah: Jurnal Studi Sosial

Volume 1 Nomor 2 Desember 2016, hal 81-90

Avaliable online at http://e-journal.ikippgrimadiun.ac.id/index.php/gulawentah

Sardjiyo, dkk. (2014). Pendidikan IPS di

$S D$. Jakarta: Universitas Terbuka.

Undang Undang Nomor 20 Tahun 2003

Tentang Sistem Pendidikan

Nasional.

Uno, H. (2009). Perencanaan

Pembelajaran. Jakarta: Bumi Aksara 